\title{
Evaluation of carambola cultivars in the Canary Islands
}

Pedro M. Hernández Delgado, Victor Galán Saúco*

Dept. Tropical Fruit, Instituto Canario de Investigaciones Agrarias (ICIA), Apartado 60, La Laguna, 38200 Tenerife,

Canary Islands, Spain
${ }^{*}$ Correspondence and reprints

Received 17 January 2001 Accepted 29 July 2002

Fruits, 2003, vol. 58, p. 19-26 (C) 2003 Cirad/EDP Sciences All rights reserved

DOI: 10.1051/fruits:2002033

RESUMEN ESPAÑOL, p. 26

\section{Evaluation of carambola cultivars in the Canary Islands.}

Abstract - Introduction. A study was set up in 1995 in the Canary Islands to determine the commercial crop potential of the carambola tree (Averrboa carambola L.) in the warmest areas of the islands. Materials and methods. Twelve carambola cultivars were planted in three blocks, at the rate of two plants per cultivar and block, under drip irrigation at a planting distance of $5 \mathrm{~m} \times 4 \mathrm{~m}$. For each cultivar, morphological and organoleptic data of the fruit were measured. Results. Results to date appear promising, with high yields and good quality fruit for all cultivars, although some have proved susceptible to fruit fly; harvesting lasts 6 to 7 months, throughout autumn and winter. Conclusion. The cultivars recommended under the Canary Island warm climatic conditions are B-17 and Sri Kembangan (short style types), and Arkin (long style type).

Spain / Canary Islands / Averrboa carambola / variety trials / agronomic characters / crop performance / quality / fruits

\section{Évaluation de cultivars de carambolier dans les îles Canaries.}

Résumé - Introduction. Une étude a été lancée en 1995 aux Canaries pour déterminer les potentialités commerciales du carambolier (Averrhoa carambola L.) dans les régions les plus chaudes de ces îles. Matériel et méthodes. Douze cultivars de carambolier ont été plantés dans trois blocs, à raison de deux plants par cultivar et par bloc. L'irrigation a été faite au goutte-à-goutte et les distances de plantation ont été de $5 \mathrm{~m} \times 4 \mathrm{~m}$. Des caractéristiques morphologiques et organoleptiques du fruit ont été évaluées pour chaque cultivar. Résultats. Les résultats semblent jusqu'ici prometteurs ; les rendements ont été élevés et le fruit a été de bonne qualité pour tous les cultivars bien que certains se soient révélés sensibles à la mouche des fruits ; la récolte, qui s'est étalée de l'automne à l'hiver, a duré 6 à 7 mois. Conclusion. Les cultivars recommandés dans le contexte des conditions climatiques chaudes des îles Canaries sont B-17 et Sri Kembangan (types à styles courts), et Arkin (type à style long).

Espagne / Canaries (îles) / Averrboa carambola / essai de variété / caractère agronomique / performance de culture / qualité / fruits 


\section{Introduction}

The first carambola cultivars were introduced in the Canary Islands from Florida early in the 1980s [1]. Limited evaluation trials over the following years were successful [2], encouraging small commercial plantings and the introduction of new plant material for further evaluation. Due to this recent introduction, right now there are only 10 ha of carambola cultivation in the Islands but prospects for small expansion are good. After the Instituto Canario de Investigaciones Agrarias (ICIA) established a new experimental station in a different locality on the island of Tenerife in 1994, a research line was established to evaluate carambola cultivars suitable for commercial planting in the Canary Islands.

As this crop is of recent introduction and no standards for cultivars appropriate for the Islands have already been established, evaluation criteria took into consideration general worldwide recommendations for this species [3-5], such as: early bearing, abundant and regular production, acceptable fruit weight (>100 g), attractive shape (five-angled shape), appropriate [acid/ sugar] ratio (total soluble solids higher than $10^{\circ}$ Brix, acidity less than $3.2 \mathrm{mg} \cdot \mathrm{g}^{-1}$ ), resistance to harvesting (thick ribs with wide angles and rounded edges), attractive color (yellow or orange), resistance to pests (mainly to fruit fly).

\section{Materials and methods}

In June 1995, an experimental trial was established at the Cueva del Polvo experimental station located at $50 \mathrm{~m}$ altitude and at $28^{\circ} 13^{\prime} \mathrm{N}$ and $16^{\circ} 50^{\prime} \mathrm{W}$ in the southwest of the island of Tenerife (table I). Twelve carambola cultivars (table II) side-grafted on 1-year-old sour carambola seedlings from seeds originally brought from Guyana were planted in three blocks, two plants per cultivar and block, at a planting distance of $5 \mathrm{~m} \times 4 \mathrm{~m}$. As is customary in the Canaries, the soil of the plot was artificially built up (0.80 $\mathrm{m}$ of andic soil over an artificial drainage layer) and the plot was

Table I.

Meteorological data at the Cueva del Polvo experimental station of ICIA in the southwest of the island of Tenerife (Canary Islands) (average 1997-2000).

\begin{tabular}{|c|c|c|c|c|c|c|c|}
\hline \multirow[t]{2}{*}{ Month } & \multicolumn{3}{|c|}{ Temperature $\left({ }^{\circ} \mathrm{C}\right)$} & \multicolumn{3}{|c|}{ Relative humidity (\%) } & \multirow{2}{*}{$\begin{array}{c}\text { Rainfall } \\
(\mathrm{mm})\end{array}$} \\
\hline & Maximum & Minimum & Average & Maximum & Minimum & Average & \\
\hline January & 20.3 & 14.8 & 17.2 & 82.7 & 52.6 & 67.8 & 39.6 \\
\hline February & 21.7 & 15.5 & 18.3 & 80.6 & 46.8 & 63.1 & 0 \\
\hline March & 22.4 & 15.9 & 18.6 & 79.7 & 46.8 & 62.7 & 2.6 \\
\hline April & 21.8 & 15.7 & 18.5 & 81.9 & 52.6 & 67.3 & 11 \\
\hline May & 22.3 & 16.6 & 19.4 & 81.7 & 54.9 & 68.5 & 0 \\
\hline June & 23.9 & 18.5 & 21.1 & 89.0 & 63.6 & 76.8 & 0 \\
\hline July & 25.1 & 19.6 & 22.0 & 91.2 & 64.2 & 79.0 & 0 \\
\hline August & 26.1 & 20.4 & 22.9 & 93.3 & 65.1 & 82.0 & 0 \\
\hline September & 25.7 & 20.3 & 22.6 & 89.8 & 63.0 & 78.8 & 1.1 \\
\hline October & 25.7 & 20.2 & 22.5 & 89.4 & 62.6 & 77.8 & 2.8 \\
\hline November & 24.3 & 18.5 & 21.0 & 84.1 & 52.0 & 67.7 & 1.9 \\
\hline December & 21.6 & 15.9 & 18.7 & 81.4 & 49.8 & 65.6 & 4.1 \\
\hline
\end{tabular}


Table II.

Source of introduction and general characteristics of twelve different carambola cultivars evaluated in the Canary Islands from 1995.

\begin{tabular}{lcccc}
\hline Cultivar & Source & Year of introduction & Canopy shape & Style type \\
\hline Arkin & Florida & 1982 & Upright & Long \\
B-6 & Australia & 1987 & Spreading & Long \\
B-10 & Malaysia & 1989 & Not defined & Short \\
B-16 & Malaysia & 1989 & Not defined & Long \\
B-17 & Malaysia & 1989 & Upright & Short \\
Fwang Tung & Florida & 1991 & Not defined & Short \\
Hart & Florida & 1991 & Not defined & Long \\
Jungle Gold & Florida & 1991 & Rounded & Spreading \\
Kary & Florida & 1991 & Not defined & Long \\
Maha & Australia & 1989 & Upright & Long \\
Sri Kembangan & Florida & 1991 & Spreading & Short \\
Thai Knight & Australia & 1989 & & Short
\end{tabular}

surrounded with 2.5-m-high windbreaks of perforated cinderblocks. Six months before planting, the soil was amended with $1.5 \mathrm{~kg}$ of calcium superphosphate per tree and, 3 months before planting, a further amendment of $0.25 \mathrm{~m}^{3}$ of goat manure per tree was dug in.

Drip irrigation was applied in increasing quantities, reaching $9500 \mathrm{~m}^{3} \cdot \mathrm{ha}^{-1}$ for the year 1999: $672 \mathrm{~L}$ per plant per week during the summer, $280 \mathrm{~L}$ per plant per week during the spring and autumn and $224 \mathrm{~L}$ per plant per week during the winter. Fertilization, through a drip irrigation system, was also applied in increasing quantities, reaching $1.32 \mathrm{~g} \mathrm{~N}, 0.82 \mathrm{~g} \mathrm{P}$ and $1.32 \mathrm{~g} \mathrm{~K}$ per plant per day in 1999, evenly distributed during the whole year. Iron chelates were applied at the beginning of the spring at the rate of a half teaspoon slightly buried under two of the drips of the irrigation system in each tree.

At the end of the harvesting season of 1997-1998, due to the excessive vigor of the trees and to damage produced by strong winds, a severe pruning was done, leaving only the main branches of the trees.
Morphological, phenological and production data were currently recorded, but only the following parameters will be discussed in this paper: the tree canopy shape (upright, spreading, rounded or not defined) observed from six non-pruned trees per cultivar; the flowering period; the type of style which can be either longer than stamens (long) or shorter than stamens (short); the harvesting period; the yield in $\mathrm{kg}$ per tree and per harvesting season; the fruit characteristics obtained from analysis of 60 fruits per cultivar: fruit weight $(\mathrm{g})$ and length $(\mathrm{mm})$; rib length $(\mathrm{mm})$, assessed by the distance from the center of the fruit to the outside tip and rib width ( $\mathrm{mm})$, measured by the distance of the base of the rib; rib slope (straight or curved); rib edge shape (rounded or sharp); skin and flesh color; shape of the fruit cross-section; preliminary panel quality from flavor of fruit slices of about $1 \mathrm{~cm}$ thickness: bad, normal, good or excellent; titrable acidity assessed with $\mathrm{NaOH} 0.1 \mathrm{~N}$ given as mg of citric acid per $\mathrm{g}$ of fruit, and total soluble solids measured with a hand refractometer in ${ }^{\circ}$ Brix. The fruit fly incidence (high, moderate or low) was studied too. 
A Tukey's mean separation test $(p<0.05)$ was done for the evaluation of yield; for the morphological fruit characteristics the parameters mean and standard deviation are given. All parameters were taken with a minimum of 20 observations.

\section{Results and discussion}

\subsection{Tree canopy shape}

All cultivars showed a great vigor, needing heavy pruning to maintain a well structured canopy, as is usual in other countries $[3,5]$. Arkin, B-17 and Sri Kembangan showed an upright growth habit while B-6, Kary and Thai Knight were spreading. Jungle Gold had a rounded canopy. The remainder did not exhibit a defined growing habit (table II).

\subsection{Flowering observations}

Practically all cultivars started flowering in the second year, according with the precocity of this species. Continued flowering was observed in all cultivars during most of the year and no alternance seemed to exist. While flowers emitted between April and January normally set fruits, those produced outside these months only occasionally led to fruit set, as expected for the cooler conditions of the winter months. This agrees with observations in a similar subtropical location in Southern Queensland [6].

Under the conditions of this experiment, long style cultivars included Arkin, B-6, B-16, Hart, Kary and Maha. Short style was exhibited by B-10, B-17, Fwang Tung, Jungle Gold, Sri Kembangan and Thai Knight. Our observations agree with those reported in the literature $[4,5]$.

\subsection{Harvesting period and yield}

In the 1997-1998 and 1999-2000 seasons, the harvesting period extended from August till February (both included) for most cultivars, except for Thai Knight which started to be cropped one month later. Due to the severe pruning done in 1998 , the harvesting period for the 19981999 season was delayed until the beginning of December and lasted until the end of March.

Broadly speaking, the most productive cultivars included Arkin, B-6, B-17 and Thai Knight. The lowest producing cultivars were B-16, Maha, Fwang Tung and Hart, the other cultivars being intermediate. However, yields were high but comparable with those reported for other carambola producing countries [5], with average yields in the 1999-2000 season not lower than 84 kg per tree (table III).

\subsection{Fruit characteristics}

\subsubsection{Fruit weight and length}

Weights ranged from $84 \mathrm{~g}$ (B-6) to $190 \mathrm{~g}$ (Fwang Tung). With the exception of B-6, Hart, Jungle Gold and Thai Knight, all the cultivars exceeded $130 \mathrm{~g}$ per fruit (table IV). Since the appropriate range for a carambola cultivar has been indicated to be between (100 and 300) g [5], all the cultivars except B-6 and Hart meet this requirement.

Only Hart had an average length shorter than $100 \mathrm{~mm}$, Fwang Tung and B-17 bearing the largest fruits. However, a big variation was observed within each cultivar. These observations, broadly speaking, do not differ from data reported for the same cultivars at the Hilo repository [7].

\subsubsection{Organoleptic characteristics}

All cultivars exhibited yellow or orange skin colors when ripe, but Maha showed a typical whitish-yellow color completely different from any other (table $\mathrm{V}$ ). Flesh color ranked from whitish yellow to orange.

There were differences between cultivars regarding total soluble solids and total titrable acids, with higher total soluble solids for B-10, B-17, Kary, Fwang Tung and Sri Kembangan, exceeding favorably the ideal values for commercial cultivars. Acidity for all cultivars was lower than the maximum values recommended for commercial cultivars $\left(<3.2 \mathrm{mg} \cdot \mathrm{g}^{-1}\right)$ [5]. B17 and Sri Kembangan showed the highest and both 
Table III.

Average yield of twelve different carambola cultivars evaluated in the Canary Islands for three harvest seasons (kg per tree per harvest season).

\begin{tabular}{|c|c|c|c|}
\hline Cultivar & 1997-1998 & 1998-1999 & 1999-2000 \\
\hline Arkin & $103 a$ & $105 a b$ & $198 a$ \\
\hline$B-6$ & $86 a$ & $117 \mathrm{a}$ & $185 a b$ \\
\hline B-10 & $72 a b c$ & $93 \mathrm{bc}$ & $146 \mathrm{bc}$ \\
\hline B-16 & $29 d$ & $42 \mathrm{e}$ & $84 \mathrm{~d}$ \\
\hline B-17 & $76 a b$ & $73 \mathrm{~cd}$ & $164 a b$ \\
\hline Fwang Tung & $45 \mathrm{~cd}$ & $46 \mathrm{e}$ & $100 d$ \\
\hline Hart & $46 \mathrm{~cd}$ & $39 \mathrm{e}$ & $100 d$ \\
\hline Jungle Gold & $92 \mathrm{a}$ & $92 \mathrm{bc}$ & $132 \mathrm{bcd}$ \\
\hline Kary & $49 \mathrm{bcd}$ & $44 \mathrm{e}$ & $108 \mathrm{bcd}$ \\
\hline Maha & $39 d$ & $38 \mathrm{e}$ & $89 \mathrm{~d}$ \\
\hline Sri Kembangan & $48 \mathrm{bc}$ & $73 \mathrm{~cd}$ & $105 \mathrm{~cd}$ \\
\hline Thai Knight & $79 a b$ & $64 \mathrm{de}$ & $160 \mathrm{abc}$ \\
\hline
\end{tabular}

Figures differ significantly $(p<0.05)$ when followed by different letters. Comparisons are always made within the same harvest season.

\section{Table IV.}

Morphological fruit characteristics measured for twelve different carambola cultivars evaluated in the Canary Islands for three harvest seasons (1997 to 2000).

\begin{tabular}{|c|c|c|c|c|c|c|}
\hline Cultivar & $\begin{array}{l}\text { Fruit weight } \\
\text { (g) }\end{array}$ & $\begin{array}{l}\text { Fruit length } \\
\qquad(\mathrm{mm})\end{array}$ & $\begin{array}{l}\text { Rib length } \\
(\mathrm{mm})\end{array}$ & $\begin{array}{l}\text { Rib width } \\
\text { (mm) }\end{array}$ & $\begin{array}{l}\text { Rib length / } \\
\text { width }\end{array}$ & $\begin{array}{l}\text { Rib slope / } \\
\text { edge shape }\end{array}$ \\
\hline Arkin & $131 \pm 22$ & $124 \pm 40$ & $20.1 \pm 1.1$ & $17.6 \pm 0.7$ & 1.1 & Straight / rounded \\
\hline B-6 & $84 \pm 30$ & $120 \pm 26$ & $20.8 \pm 3.9$ & $14.7 \pm 1.0$ & 1.4 & Curved / sharp \\
\hline B-10 & $157 \pm 40$ & $122 \pm 29$ & $23.0 \pm 2.1$ & $16.8 \pm 0.1$ & 1.4 & Curved / sharp \\
\hline B-16 & $140 \pm 53$ & $112 \pm 36$ & $20.2 \pm 1.1$ & $17.3 \pm 0.9$ & 1.2 & Straight / sharp \\
\hline B-17 & $139 \pm 44$ & $136 \pm 33$ & $18.7 \pm 1.8$ & $16.9 \pm 0.8$ & 1.1 & Curved / rounded \\
\hline Fwang Tung & $190 \pm 56$ & $132 \pm 44$ & $26.4 \pm 2.0$ & $19.4 \pm 0.9$ & 1.4 & Curved / rounded \\
\hline Hart & $86 \pm 22$ & $88 \pm 29$ & $19.7 \pm 2.2$ & $14.6 \pm 0.9$ & 1.3 & Straight / sharp \\
\hline Jungle Gold & $119 \pm 38$ & $107 \pm 45$ & $22.6 \pm 3.0$ & $17.8 \pm 0.8$ & 1.3 & Curved / rounded \\
\hline Kary & $148 \pm 35$ & $107 \pm 52$ & $21.4 \pm 0.8$ & $16.8 \pm 0.8$ & 1.3 & Curved / sharp \\
\hline Maha & $140 \pm 24$ & $116 \pm 29$ & $20.7 \pm 1.4$ & $18.2 \pm 1.0$ & 1.1 & Straight / sharp \\
\hline Sri Kembangan & $139 \pm 25$ & $128 \pm 43$ & $20.4 \pm 2.9$ & $18.1 \pm 1.8$ & 1.1 & Curved / rounded \\
\hline Thai Knight & $110 \pm 13$ & $110 \pm 30$ & $21.7 \pm 2.6$ & $14.9 \pm 0.5$ & 1.5 & Curved / sharp \\
\hline
\end{tabular}




\begin{tabular}{|c|c|c|c|c|c|c|c|}
\hline Cultivar & Skin color & Flesh color & Fruit shape & Flavor & $\begin{array}{c}\text { Acidity } \\
\left(\mathrm{mg} \text { citric acid } \cdot \mathrm{g}^{-1}\right)\end{array}$ & $\begin{array}{c}\text { Total soluble } \\
\text { sugars } \\
\text { ( }{ }^{\circ} \text { Brix) }\end{array}$ & $\begin{array}{c}\text { [Total soluble } \\
\text { sugars / acidity] ratio }\end{array}$ \\
\hline Arkin & $\begin{array}{l}\text { Yellow-orange, } \\
\text { green borders }\end{array}$ & $\begin{array}{l}\text { Yellow- } \\
\text { orange }\end{array}$ & Ellipsoidal & Normal & 2.54 & 8.6 & 3.39 \\
\hline B-6 & Orange & Orange & Ellipsoidal & Normal & 2.64 & 8.6 & 3.27 \\
\hline$B-10$ & Yellow-orange & $\begin{array}{l}\text { Yellow- } \\
\text { orange }\end{array}$ & Elongated & Normal & 2.39 & 10.3 & 4.28 \\
\hline$B-16$ & Yellow-orange & $\begin{array}{l}\text { Yellow- } \\
\text { orange }\end{array}$ & Ellipsoidal & Normal & 3.03 & 7.0 & 2.31 \\
\hline B-17 & Yellow-orange & $\begin{array}{l}\text { Yellow- } \\
\text { orange }\end{array}$ & Ellipsoidal & Excellent & 2.61 & 10.7 & 4.08 \\
\hline Fwang Tung & Yellow & Yellow & Ovoid & Normal & 2.72 & 10.1 & 3.72 \\
\hline Hart & $\begin{array}{l}\text { Greenish } \\
\text { yellow }\end{array}$ & $\begin{array}{l}\text { Whitish } \\
\text { yellow }\end{array}$ & Ellipsoidal & Bad & 2.27 & 9.0 & 3.97 \\
\hline Jungle Gold & $\begin{array}{l}\text { Greenish } \\
\text { yellow }\end{array}$ & $\begin{array}{l}\text { Whitish } \\
\text { yellow }\end{array}$ & Ovoid & Good & 3.06 & 8.5 & 2.78 \\
\hline Kary & Yellow-orange & $\begin{array}{l}\text { Yellow- } \\
\text { orange }\end{array}$ & Ellipsoidal & Normal & 2.95 & 10.8 & 3.65 \\
\hline Maha & Whitish yellow & Yellow & Ovoid & Normal & 3.02 & 8.0 & 2.65 \\
\hline $\begin{array}{l}\text { Sri } \\
\text { Kembangan }\end{array}$ & Yellow & Yellow & Elongated & Excellent & 2.58 & 10.5 & 4.07 \\
\hline Thai Knight & $\begin{array}{l}\text { Yellow-orange, } \\
\text { green borders }\end{array}$ & Orange & Ellipsoidal & Good & 2.55 & 9.9 & 3.88 \\
\hline
\end{tabular}

very similar [total soluble solids/ acidity] ratio, only surpassed by B-10 due to its lower acidity, which makes them more suitable for fresh consumption. In fact, the preliminary panel survey done with fruit slices indicated clearly an excellent taste for the cultivars B-17 and Sri Kembangan. Although B-17 did not have the highest total soluble solids values (15-18 ${ }^{\circ}$ Brix) reported for Malaysia, all the others are on the normal rank obtained elsewhere for these cultivars [5].

\subsubsection{Other characteristics}

The cultivars Arkin, B-17, Maha and Sri Kembangan exhibited the smallest rib [length / width] ratio which, in principle, would favor their marketing. On the other hand, the sharply pointed rib shape of Maha is a serious defect for postharvest handling, also reported in other countries [8] (table IV, figure 1).

\subsection{Pest and disease incidences}

The main pest observed was the Mediterranean fruit fly (Ceratitis capitata Wied.), controlled with regular applications of fenthion at early fruit stages and pyrethrins. All cultivars were susceptible to this pest, but Sri Kembangan and Fwang Tung showed the highest susceptibly and B-10 and Hart the least (table VI). Attacks of Polyphagotarsonemus latus Banks (broad mite) and aphids sporadically occurred. 


\section{Conclusion}

For all the trees, the vigor was very high, needing strong pruning to avoid branch breaking due to the load of the fruit and to sporadic winds.

The trees showed a short juvenile period, as normal in this species, with very good yields from the second year of planting and, during the following years, yields similar to other producing countries [6]. The harvesting period is long for a subtropical location.

The fruit characteristics seemed to be similar to the standard for the different cultivars [6, 7], with good fruit size, appearance and flavor for various cultivars, adapted to the market requirements of western consumers.

Within the short style cultivars, B-17 and Sri Kembangan (figure 2) produced fruit of the best quality. B-17 was also a cultivar with high yields. The long style cultivar Arkin (figure 2) was also high yielding although its flavor was not as sweet as B-17 and Sri Kembangan. These three cultivars are currently recommended for cultivation under the Canary Islands' warm climatic conditions.

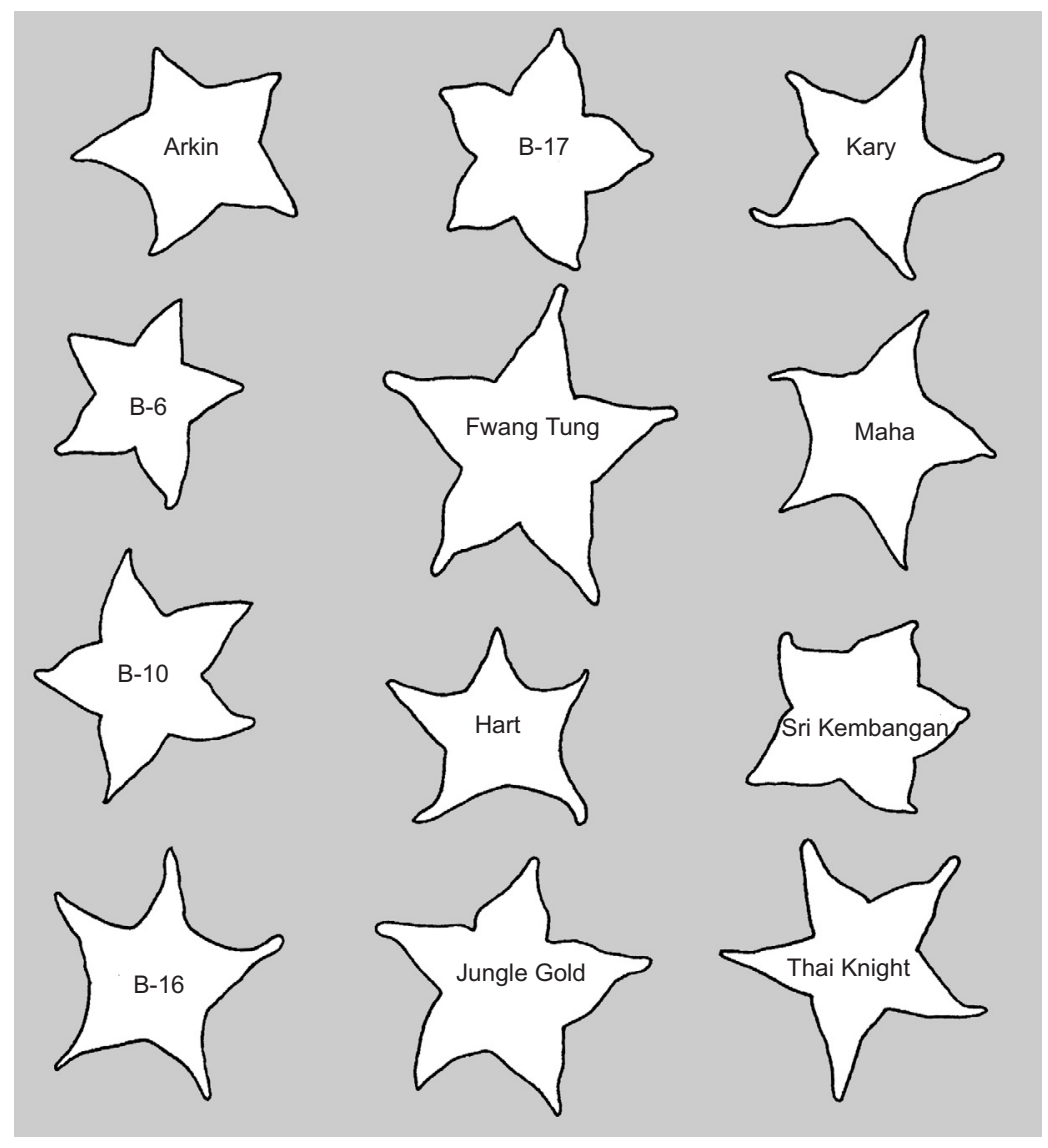

Figure 1.

Representative cross-sections of twelve different carambola cultivars evaluated in the Canary Islands.

\begin{tabular}{ll}
\hline Cultivar & Incidence \\
Arkin & Moderate \\
B-6 & Moderate \\
B-10 & Low \\
B-16 & Moderate \\
B-17 & Moderate-high \\
Fwang Tung & High \\
Hart & Low \\
Jungle Gold & Moderate \\
Kary & Moderate \\
Maha & Moderate \\
Sri Kembangan & High \\
Thai Knight & Moderate
\end{tabular}


Figure 2.

Fruit of the three cultivars recommended under the Canary Islands' warm climatic_ conditions: B-17 and Sri Kembangan (short style types); Arkin (long style type).

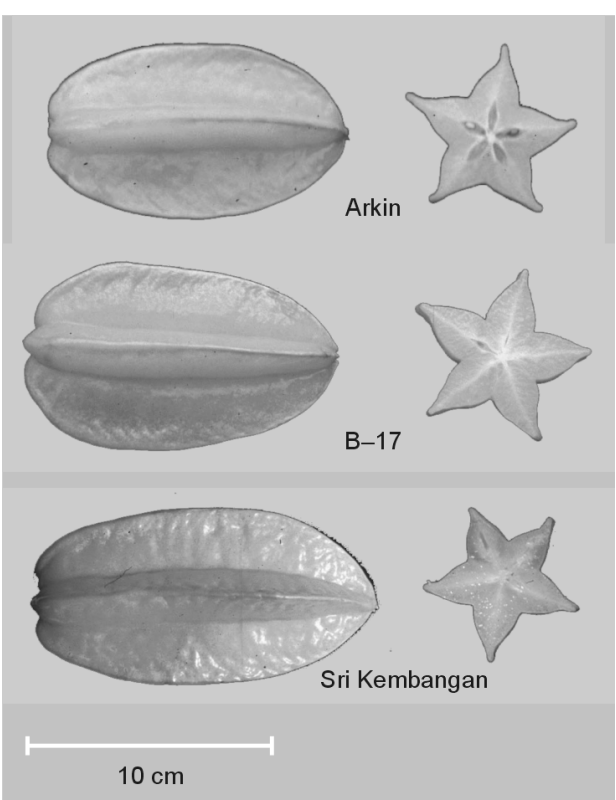

\section{References}

[1] Hernandez Delgado P.M., Galán Sauco V., The potential of carambola for the Canary Islands, in: Vijaysegaran S., Pauziah M., Mohamed M.S., Ahmad Tarmizi S. (Compilers), Proc. Int. Conf. Trop. Fruits, Malays. Agric. Res. Dev. Inst., Kuala Lumpur, Malaysia, Vol. III, 1996, pp. 109-112.

[2] Galán Sauco V., Hernandez Delgado P.M., Fernandez Galvan D., Preliminary observa- tions on carambola in the Canary Islands, in: Lamberts M. (Ed.), Proc. Interam. Soc. Trop. Hortic., 33, Interam. Soc. Trop. Hortic., Georgetown, Guyana, 1989, pp. 55-58.

[3] Campbell C.W., Propagation and production systems for carambola, in: Lamberts $M$. (Ed.), Proc. Interam. Soc. Trop. Hortic., 33, Interam. Soc. Trop. Hortic., Georgetown, Guyana, 1989, pp. 66-71.

[4] Knight R.J. Jr., Carambola cultivars and improvement programs, in: Lamberts $M$. (Ed.), Proc. Interam. Soc. Trop. Hortic., 33, Interam. Soc. Trop. Hortic., Georgetown, Guyana, 1989, pp. 72-78.

[5] Galan Sauco V., Menini U., Carambola cultivation, FAO Plant Production and Protection Paper, Roma, Italy, 1990, 73 p.

[6] Watson B.J., George A.P., Nissen R.J., Brown B.I., Carambola: a star on the horizon, Queensland Agr. J. 114 (1) (1988) 45-51.

[7] Anonymous, ARS, National Genetic Resources Program, Germplasm Resources Information Network (GRIN), USDA, Online Database, National Germplasm Resources Laboratory, Beltsville, Maryland, 2000, available: www.ars-grin.gov/cgi-bin/npgs/html/ site.pl?HILO.

[8] Campbell C.W., Carambola production in the United States, in: Lamberts M. (Ed.), Proc. Interam. Soc. Trop. Hortic., 33, Interam. Soc. Trop. Hortic., Georgetown, Guyana, 1989, pp. 47- 54 .

\section{Evaluación de cultivares de carambola en las Islas Canarias.}

Resumen - Introducción. En 1995 se inició un estudio de doce cultivares de carambola (Averrboa carambola L.) con el fin de determinar su potencial como cultivo comercial en las zonas más cálidas de las Islas. Material y métodos. Se plantaron doce cultivares de carambola en tres bloques con dos plantas por cultivar y bloque, con riego por goteo y a un marco de plantación de $5 \mathrm{~m} \times 4 \mathrm{~m}$. Para cada cultivar se tomaron datos tanto de características morfológicas como organolépticas de los frutos. Resultados. Los resultados hasta la fecha parecen prometedores, con rendimientos altos y buena calidad de fruto para todos los cultivares, aunque algunos han mostrado susceptibilidad a la mosca de la fruta, la recolección se realiza durante 6-7 meses en otoño-invierno. Conclusión. Los cultivares recomendados para las zonas de clima cálido de Canarias son B-17 y Sri Kembangan (estilo corto) y Arkin (estilo largo).

España / Canarias / Averrboa carambola / ensayos de variedades / características agronómicas / productividad / calidad / frutas 